\title{
Effect of brief interventions in reducing alcohol consumption among individuals with human immunodeficiency virus
}

\author{
Efeito das intervençóes breves na redução do consumo de álcool em indivíduos portado- \\ res do vírus da imunodeficiência humana \\ Efecto de las intervenciones breves para reducir el consumo de alcohol en los individuos \\ con virus de la inmunodeficiencia humana \\ Susana Magalhães Patrício*; Deborah S. Finnell**; Teresa Barroso***
}

\begin{abstract}
Background: Alcohol consumption in individuals with the human immunodeficiency virus (HIV) may influence disease progression due to its influence on therapeutic adherence.

Objectives: To evaluate the effect of brief interventions in reducing the risk of alcohol consumption among individuals with HIV. Methodology: Experimental study with a control group. Consecutive sampling. Brief interventions were performed in the experimental group (31 participants) and usual teaching were provided to the control group (27 participants), after application of the Alcohol Use Disorders Identification Test (AUDIT). A structured questionnaire was also used to characterize the participants. Participants were later assessed at a 4- and 6-month follow up.

Results: At baseline, both groups were homogeneous and the final assessment showed statistically significant differences $(p=.028)$ in the risk of alcohol consumption. After the intervention, 2 participants in the experimental group decreased the risk of alcohol consumption from the hazardous risk zone to the low risk zone.

Conclusion: Despite borderline significance, brief interventions proved to have a more positive impact than usual teaching in reducing the risk of alcohol consumption.
\end{abstract}

Keywords: motivation; evaluation of effectiveness-efficiency of interventions; alcohol consumption; VIH; nursing

\section{Resumo}

Enquadramento: O consumo de álcool em indivíduos portadores do vírus da imunodeficiência humana (VIH) pode influenciar a progressão da doença pela diminuição da adesão à terapêutica. Objetivos: Avaliar o efeito das intervenções breves na redução do risco de consumo de álcool nos indivíduos portadores de VIH. Metodologia: Estudo experimental, com grupo de controlo. Amostragem consecutiva. Realizadas intervenções breves no grupo experimental (31 indivíduos) e ensinos habituais no de controlo (27 indivíduos), após aplicação Alcohol Use Disorders Identification Test (AUDIT).. Recurso também a questionário estruturado para caracterização dos participantes. Avaliação seguinte após 4 a 6 meses.

Resultados: Na avaliação inicial, os grupos eram homogéneos e na avaliação final demonstraram diferenças estatisticamente significativas $(p=0,028)$ no risco de consumo de álcool. Após a intervenção, 2 indivíduos do grupo experimental diminuíram o risco de consumo de álcool, passando da zona de risco para a de baixo risco.

Conclusão: Embora no limiar da significância, as intervenções breves demonstraram ter efeitos mais positivos, comparativamente aos ensinos habituais, na redução do risco de consumo de álcool.

Palavras-chave: motivação; avaliação de eficácia-efetividade das intervenções; consumo de bebidas alcoólicas; HIV; enfermagem

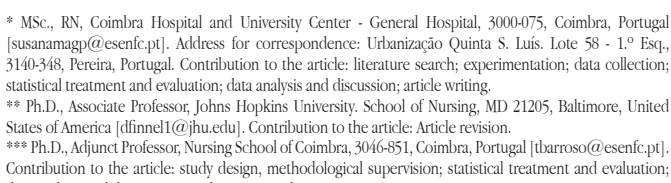

* MSc., RN, Coimbra Hospital and University Center - General Hospital, 3000-075, Coimbra, Portugal [susanamagp@esenfc.pt]. Address for correspondence: Urbanização Quinta S. Luís. Lote 58 - 1. ${ }^{\circ}$ Esq., 3140-348, Pereira, Portugal. Contribution to the article: literature search; experimentation; data collection; statistical treatment and evaluation; data analysis and discussion; article writing.

* Ph.D., Associate Professor, Johns Hopkins University. School of Nursing, MD 21205, Baltimore, United States of America [dfinnel1@jhu.edu].Contribution to the article: Article revision.

*** Ph.D., Adjunct Professor, Nursing School of Coimbra, 3046-851, Coimbra, Portugal [tbarroso@esenfc.pt]. Contribution to the article: study design, methodological supervision; statistical treatment and evaluation; data analysis and discussion; article writing and revision.

\section{Resumen}

Marco contextual: El consumo de alcohol en individuos con virus da imunodeficiencia humana (VIH) puede influir en el desarrollo de la enfermedad por la disminución de adhesión a la terapia.

Objetivos: Evaluar el efecto de las intervenciones breves para reducir el riesgo de consumo de alcohol en individuos con VIH. Metodología: Estudio experimental con un grupo de control y con una muestra consecutiva. Se realizaron intervenciones breves en el grupo experimental (31 individuos) y una enseñanza babitual en el de control (27 individuos) después de aplicar el Alcobol Use Disorders Identification Test (AUDIT).. También se utilizó un cuestionario estructurado para caracterizar a los participantes. La siguiente evaluación se realizó de los 4 a los 6 meses siguientes.

Resultados: En la evaluación inicial los grupos fueron homogéneos y en la evaluación final mostraron diferencias estadísticamente significativas $(p=0,028)$ en el riesgo de consumo de alcohol. Después de la intervención, 2 sujetos del grupo experimental redujeron el riesgo de consumo de alcohol, pasando así de la zona de riesgo a la de riesgo bajo.

Conclusión: A pesar de la significación marginal, las intervenciones breves demostraron que tienen efectos más positivos en comparación con la enseñanza habitual en la reducción del riesgo de consumo de alcohol.

Palabras clave: motivación; intervenciones breves; evaluación de eficacia-efectividad de intervenciones; consumo de bebidas alcohólicas; VIH; enfermería

Received for publication: 06.07.16 Accepted for publication: 25.10 .16 


\section{Introduction}

Since its discovery in the 1980s, the Human Immunodeficiency Virus (HIV) has affected millions of people worldwide. Although HIV was initially associated with homosexuals, today all groups are affected by HIV. In Portugal, HIV has been increasing among heterosexuals and decreasing among drug addicts and homosexuals (Instituto Nacional de Saúde Dr. Ricardo Jorge, 2015), following global trends (Joint United Nations Programme on HIV/AIDS, 2016).

With the development of antiretroviral therapy, the average life expectancy of individuals with HIV has increased significantly, and it has become a manageable chronic disease, instead of a fatal disease. Thus, therapeutic adherence is essential for these individuals, since it is considered the second leading predictor of disease progression (Machtinger \& Bangsberg, 2006).

However, adherence can be influenced by several factors. Individuals with HIV who consume alcohol are known to be less likely to adhere to treatment (Bryant, Nelson, Braithwaite, \& Roach, 2010; World Health Organization [WHO], 2003). This situation becomes worrying when alcohol consumption among these patients is almost two times that of the general population (Chander, Lau, \& Moore, 2006; Szabo \& Zakhari, 2011). In this context, screening and interventions are essential for alcohol-related problems in individuals undergoing antiretroviral medication, particularly in stable periods (Tran, Nguyen, Do, Nguyen \& Maher, 2014).

In order to reduce alcohol consumption levels and refer individuals with alcohol dependence for specialized treatment, the World Health Organization (WHO) recommends the use of the Alcohol Use Disorders Identification Test (AUDIT) for screening (WHO, 2014). In Portugal, the Directorate-General for Health puts forward clear guidelines (standard no. 30) for the early detection and brief intervention in alcohol abuse using the AUDIT. Brief interventions (BIs) are developed according to the risk level identified in this test. These interventions are based on the motivational approach, are characterized by their low intensity and short duration, and can range between educational intervention and simple to brief advice (Babor \& Higgins-Bidlle, Saunders, Monteiro, 2001).
Due to the relevance of alcohol consumption among patients with HIV and its implications in therapeutic adherence and disease progression, this study aimed to assess the effect of BIs in reducing the risk of alcohol consumption among individuals with HIV followed-up in a specialized consultation. These BIs were carried out by psychiatric and mental health nurses, who, due to their specific set of skills, are the most competent professionals to understand and assess the ability and willingness of each individual to change and adopt healthier behaviors.

\section{Background}

The Human Immunodeficiency Virus (HIV) gradually deteriorates the immune system, causing a state of immunodeficiency and inability to fight against infections and diseases. This virus has infected approximately 71 million people and killed 31 million people around the world (Joint United Nations Programme on HIV/AIDS, 2016).

According to the recent report of the Joint United Nations Programme on HIV/AIDS (2016), ending the Acquired Immuno Defeciency Syndrome (AIDS) epidemic by 2030 seems to be a tangible target. In the past 15 years, many achievements have been registered regarding HIV treatment, particularly in the use of antiretroviral therapy, which reached 17 million of the 36.7 million people living with HIV in 2015. This allowed reducing by $43 \%$ the number of AIDS-related deaths since 2003 (Joint United Nations Programme on HIV/AIDS, 2016).

In Portugal, according to the report issued in 2015 by the National Institute of Health Dr. Ricardo Jorge, on 31 December 2014, 52,694 cases were identified, 20,856 of which were in the AIDS stage (Instituto Nacional de Saúde Dr. Ricardo Jorge, 2015). According to this report, with regard to the number of deaths reported, there was a downward trend in the annual number of deaths in cases of HIV infection and AIDS. Although the number of new cases of HIV infection has been reducing over the past decade, Portugal continues to be one of the European countries with a higher annual rate of new cases.

Since this is not yet a curable disease, antiretroviral therapy is merely used to control the virus, reducing the number of comorbidities, and improving 
the patients' quality of life; restore and preserve the immune system; decrease the viral load and, subsequently, decrease virus transmission (Bonolo, Gomes, \& Guimarães, 2007). Machtinger and Bangsberg (2006) consider therapeutic adherence in these patients to be the second leading predictor of disease progression. Alcohol is known to be an influencing factor to therapeutic adherence, and alcohol consumption is frequent among these individuals, maybe due to its relaxing effects, which are very similar to the pharmacological and behavioral effect of benzodiazepines (Lingford-Hughes, Potokar, \& Nutt, 2002).

Portugal is one of the European countries with higher consumption of pure alcohol per capita (12.9 liters), well above the European average of 10.91 (WHO, 2014). With regard to heavy alcohol consumption and dependence patterns, in 2012, approximately 3.0\% of the population aged 15 to 64 years had a hazardous/ harmful risk of alcohol consumption and $0.3 \%$ of dependence (Balsa, Vital, \& Urbano, 2013).

Studies point to the need to raise awareness among the population and to develop more specific and targeted interventions for individuals with harmful consumption and potential alcohol dependence (Barroso, Castanhola, Marta, Claro, 2010; Kaner et al., 2007; McCambridge \& Kypri 2011; Rosa, Abreu, \& Barroso, 2015). In its report Global strategy to reduce the barmful use of alcobol, WHO (2010) also indicates the need to develop initiatives for the early detection of hazardous and heavy alcohol consumption and referral of individuals with probable dependence, not only in primary health care, but also in other settings. Along with the early detection, WHO also advocates the implementation of BIs for the reduction of alcohol consumption. In this context of reducing the risk of alcohol consumption, BIs are developed after the identification of the individual's risk level using the AUDIT. Depending on the risk level, different interventions are implemented, which should not last more than 60 minutes. These may be educational, simple advice or brief advice interventions, associated with a motivational approach if justified by the risk level (Babor et al., 2001). In a study aimed to assess the effect of BIs in reducing harmful alcohol consumption among patients undergoing methadone treatment, Rosa and colleagues (2015) found that these interventions had a positive effect in reducing this type of consumption.

\section{Hypotheses}

BIs have a positive effect in reducing the risk of alcohol consumption of individuals with HIV being followed-up in a consultation for infectious diseases at a Day Hospital, when compared with individuals who only undergo the usual teaching method.

\section{Methodology}

This was an experimental study with a control group $(n=27)$ and an experimental group $(n=31)$. Both groups were assessed in two moments. In the first assessment, the AUDIT was applied as a diagnostic test of the participants' risk of alcohol consumption. In the experimental group, after the test was applied, the protocol of BIs was implemented by the psychiatric and mental health nurse with specific training. In the control group, after the application of the AUDIT, the usual teaching protocol was applied by a general nurse. The second assessment (after the intervention) occurred 4 to 6 months after the initial assessment. The AUDIT was again applied to the participants of both groups for comparison of results. This study sample was composed of individuals with HIV being followed-up in the Day Hospital of Infectious Diseases of the General Hospital of the Coimbra Hospital and University Center (CHUC). This was a consecutive sample and subjects were distributed according to the following procedure: the control group was composed of individuals with medical consultation on Mondays and Wednesdays and the experimental group consisted of subjects with consultation on Tuesdays and Thursdays. This weekly distribution was randomly made.

The groups belong to the same population. Their homogeneity was analyzed and no statistically significant differences were found concerning the sociodemographic variables, the variables related to disease history and antiretroviral therapy, and the risk of alcohol consumption.

The following criteria for inclusion in the study were applied: individuals who were diagnosed with HIV infection and followed-up in consultation in the Day Hospital of Infectious Diseases of the General Hospital of the CHUC; were literate, and able to communicate and understand; and were aged over 18 years old. The 
following exclusion criteria were applied: individuals who were diagnosed with a cognitive disorder, dementia or other cognitive impairment; were active users of other psychoactive substances other than alcohol; and were imprisoned.

Data were collected through a structured questionnaire divided into three parts: the first part addressed sociodemographic data, the second part covered the disease history (HIV) and antiretroviral therapy, and the third part consisted of questions related to the consumption of psychoactive substances and the AUDIT. This diagnostic test consists of 10 questions (scored from 0 to 4 ) on the recent alcohol consumption (last 12 months), symptoms of dependency and alcohol-related problems. The total score is the sum of the 10 individual scores and characterizes the individual's level of risk for alcohol consumption (Babor et al., 2001). The total score ranges from 0 to 40, and the higher the score, the higher the risk for alcohol consumption. Scores can also be grouped into different risk levels: 0 corresponds to abstainer, 1-7 corresponds to low-risk drinkers, 8-15 corresponds to hazardous drinkers, 16-19 corresponds to harmful drinkers, and 20 or more corresponds to drinkers with probable alcohol dependence. The AUDIT was validated in Portugal by Roque da Cunha in 2002. It has 83-92\% of sensitivity and 92-98\% of specificity (Silva \& Quintas, 2010).

In order to verify the reliability of the instrument (AUDIT), the Cronbach's alpha coefficient was used to verify its internal consistency in both moments. The Cronbach's alpha was .751 and .777 in the first and second assessments, respectively. As regards the item-total correlation, the scores ranged from .000 to .703 , and from .000 to .724 in the first and second assessment, respectively. The AUDIT proved to be a consistent instrument.

The dependent variable in this study was the risk of alcohol consumption (measured through the total AUDIT score) and the independent variable was the BIs. This study is associated with the project Health without reservations of the Health Sciences Research Unit: Nursing (UICISA:E) and is developed based on the protocol for BIs adapted from Babor et al. (2001). It includes systemized scripts for each intervention and a leaflet that is distributed to each individual. The protocol includes the assessment using the AUDIT and the development of BIs, depending on the levels of risk identified. In Zone I, low-risk consumption (scores 0-7), the intervention developed is Alcohol Education, which consists of feedback about the screening test and positive reinforcement for the individual to be at this level; clarification of the guidelines for low risk consumption and information about potential hazard if consumption increases. In Zone II, hazardous consumption (scores 8-15), the intervention uses Simple Advice: feedback on the AUDIT is also provided and information is made available in writing, which is first analyzed together with the individual, about the possible effects of continuing this type of consumption. The guidelines for low risk consumption are highlighted and, if possible, an objective is set out, in collaboration with the individual, to reduce or stop alcohol consumption, encouraging him/her to do so. In Zone III, harmful consumption (scores 16-19), the intervention consists of Simple Advice plus Brief Counseling and Continued Monitoring and offers a more direct motivational approach, allowing the individual to express the reasons for not changing his/her consumption behavior or, where appropriate, setting out individual goals and strategies for reducing consumption (if the individual is in an adequate motivational stage). Finally, in Zone IV, probable alcohol dependence (score 20 or more), it is necessary to refer the patient to diagnosis and treatment. Data were analyzed using the statistical software SPSS (Statistical Package for the Social Sciences), version 19.0. Since these were two independent samples from the same population, in which the assumption of normality was not observed ( $p=.000$ for both groups in the Shapiro-Wilk test used in samples with less than 50 subjects), we decided to use non-parametric tests (Mann-Whitney U-test). All participants were informed of the purpose and objectives of the study. Only those individuals who gave their written consent participated in the study. The study was approved by the Ethics Committee of the Hospital where it was conducted.

\section{Results}

The initial sample was composed of 58 individuals: 31 were allocated to the experimental group, and 27 to the control group. The mean age was 46.52 years $(S D=10.414)$ and 42.52 years $(S D=6.980)$ in the control group and in the experimental group, respectively. The male gender was predominant 
in both groups: 25 men in the experimental group, and 23 in the control group. In both groups, most individuals had Portuguese nationality: 29 individuals in the experimental group (93.5\%), and 22 in the control group. Most of them lived with their family: 19 individuals in the experimental group, and 17 in the control group. With regard to education, most individuals had primary education: 11 individuals $(35.5 \%)$ in the experimental group, and 12 in the control group. With regard to marital status, most individuals were single: 11 individuals in the experimental group, and 14 in the control group.

Table 1

Sociodemographic characteristics

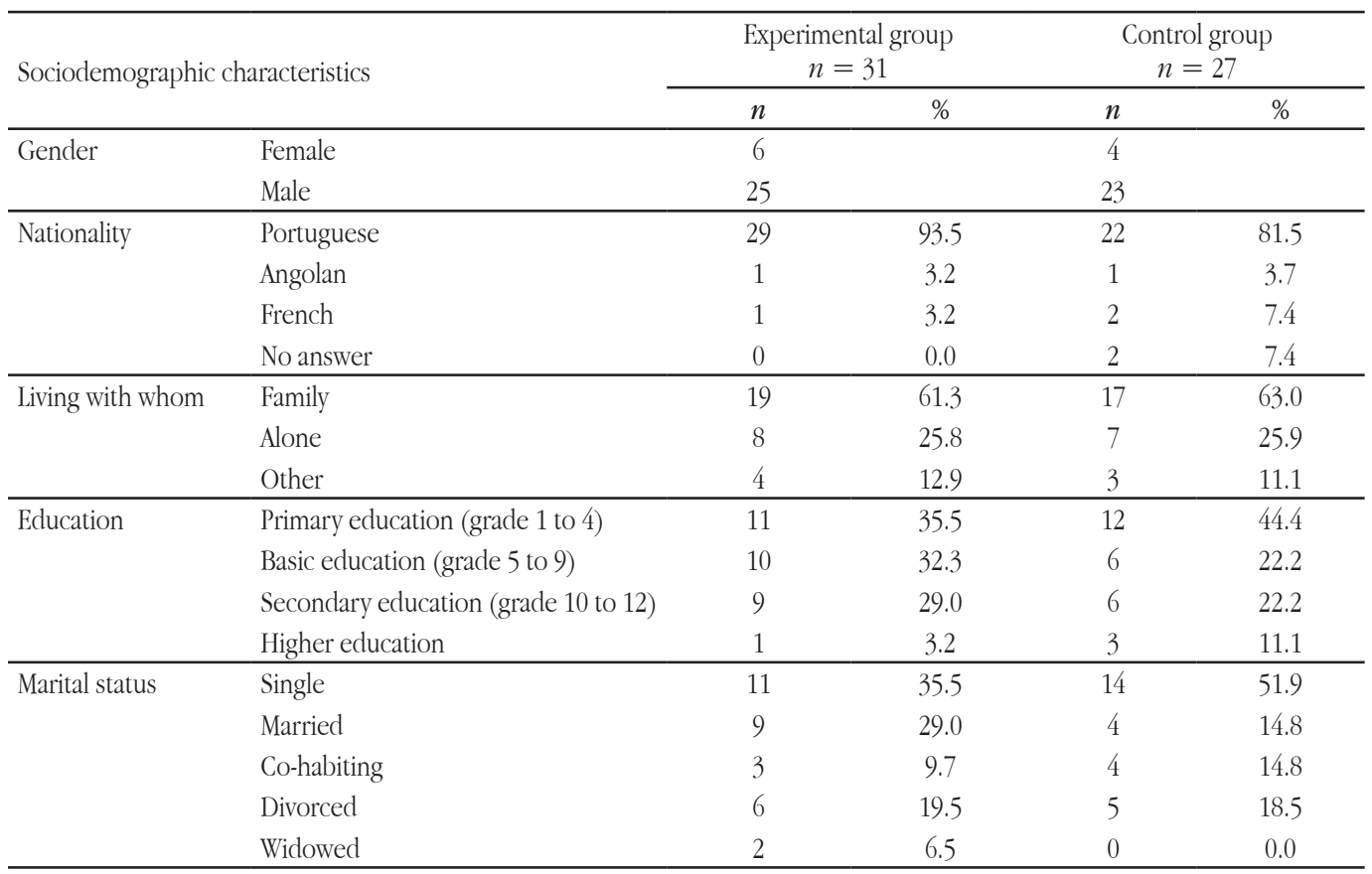

With regard to HIV diagnosis and treatment, participants in the experimental group were aware of their diagnosis for approximately 9.22 years $(S D=$ 6.31), and in the control group for 9.96 years ( $S D=$ 6.11); $4(S D=12.9)$ individuals in the experimental group and $4(S D=14.8)$ in the control group took no antiretroviral medication; and 27 participants in the experimental group were taking this medication on average for 8.52 years $(S D=5.86)$, and 23 in the control group for 10.39 years $(S D=5.13)$. With regard to compliance with medical prescriptions, $88.9 \%$ of participants undergoing ART in the experimental group, and $91.3 \%$ of participants in the control group report compliance.

With regard to disease progression, more than half of the individuals in both groups had an undetectable or below 50 copies/ml viral load. In the experimental group, $58.1 \%$ of the participants had an undetectable or below 50 copies/ml viral load in both assessments. In the control group, $74.1 \%$ of the participants in the first assessment and $66.7 \%$ (18) of the participants in the second assessment had a negative or undetectable viral load. 
Table 2

Comparison of the sample in relation to alcohol consumption risk levels, before and after BIs

\begin{tabular}{|c|c|c|c|c|c|c|}
\hline \multirow{2}{*}{\multicolumn{2}{|c|}{ Characteristics of the levels of consumption }} & & \multicolumn{2}{|c|}{$\begin{array}{c}\text { Experimental group } \\
n=31\end{array}$} & \multicolumn{2}{|c|}{$\begin{array}{c}\text { Control group } \\
n=27 \\
\end{array}$} \\
\hline & & & No. & $\%$ & No. & $\%$ \\
\hline \multirow{2}{*}{$\begin{array}{c}\text { ZONE I } \\
(0-7)\end{array}$} & \multirow[t]{2}{*}{ Low-Risk } & Before & 29 & 93.5 & 23 & 85.2 \\
\hline & & After & 31 & 100.0 & 24 & 88.9 \\
\hline \multirow{2}{*}{$\begin{array}{c}\text { ZONE II } \\
(8-15) \\
\end{array}$} & \multirow[t]{2}{*}{ Hazardous } & Before & 2 & 6.5 & 3 & 11.1 \\
\hline & & After & 0 & 0.0 & 2 & 7.4 \\
\hline \multirow{2}{*}{$\begin{array}{c}\text { ZONE III } \\
(16-19) \\
\end{array}$} & \multirow[t]{2}{*}{ Harmful } & Before & 0 & 0.0 & 1 & 3.7 \\
\hline & & After & 0 & 0.0 & 1 & 3.7 \\
\hline
\end{tabular}

Depending on the risk levels identified, 29 educational interventions were developed in the experimental group, corresponding to 29 individuals who had a low-risk level of consumption in the first assessment and two simple advice interventions to the individuals in the hazardous consumption zone. After the development of the BIs, no individual was in the hazardous consumption zones, and all individuals in the experimental group were in the low-risk zone. In the control group, all individuals (27) received the usual teaching intervention. Although one individual reduced the risk level to the low-risk consumption, the other two individuals who were in the hazardous consumption zone and the single participant in the harmful consumption zone in the first assessment remained in the same zone in the second assessment, after the "usual teaching".

\section{Effect of brief interventions}

We performed the Mann-Whitney U-test to test the research hypothesis.

As Table 3 shows, before the BIs, there were no statistically significant differences $(p=.207)$ in the risk of alcohol consumption between groups. After the intervention, the risk of alcohol consumption decreased in the experimental, and increased in the control group. In addition, statistically significant differences were found $(p=.028)$ between the groups (experimental and control) after the intervention. Thus it can be concluded that the experimental group evolved towards lower risk.

Table 3

Research hypothesis test: application of the Mann-Whitney U-test on the sum before and after the implementation of brief interventions

\begin{tabular}{|c|c|c|c|c|}
\hline & $\begin{array}{l}\text { Experimental group } \\
n=31\end{array}$ & $\begin{array}{l}\text { Control group } \\
\mathrm{n}=27\end{array}$ & $\begin{array}{l}\text { Experimental group } \\
\mathrm{n}=31\end{array}$ & $\begin{array}{l}\text { Control group } \\
n=27\end{array}$ \\
\hline & $\begin{array}{l}\text { Initial assessment } \\
\text {-Initial sum }\end{array}$ & $\begin{array}{l}\text { Initial assessment } \\
\text {-Initial sum }\end{array}$ & $\begin{array}{l}\text { Final assessment } \\
\text {-Final sum }\end{array}$ & $\begin{array}{l}\text { Final assessment } \\
\text {-Final sum }\end{array}$ \\
\hline \multirow[t]{2}{*}{ Mean rank } & 26.94 & 32.44 & 25.06 & 34.59 \\
\hline & $\begin{array}{l}\text { Mann-Whitney U-test }=339 \\
Z=-1.263 \\
p=.207\end{array}$ & & $\begin{array}{l}\text { Mann-Whitney U-test }=281 \\
Z=-2.195 \\
p=.028\end{array}$ & \\
\hline
\end{tabular}

We analyzed the difference in the sums before and after the implementation of BIs in order to better understand the groups' evolution. As Table 4 shows, the difference in the groups' evolution is on the threshold of significance, with $p=.051$. 
Table 4

Research bypothesis test: application of the Mann-Whitney U-test on the difference of sums before and after the implementation of brief interventions

\begin{tabular}{lll}
\hline & Before-after difference in the sum & \\
\hline \multirow{3}{*}{ Mean rank } & Experimental group & Control group \\
& 25.63 & 33.94 \\
& Mann-Whitney U-test $=298.500$ & \\
$Z=-1.951$ & \\
$p=.051$ & \\
\hline
\end{tabular}

\section{Discussion}

One of the study limitations was the lack of a nonprobability distribution of the subjects into the control and experimental groups, and the size of the sample, which can jeopardize internal and external validity. On the other hand, considering the follow-up period of only 4 and 6 months, further studies are needed to validate the stability of these results over time. With regard to the characterization of alcohol consumption based on the AUDIT levels before and after the implementation of BIs (quantity and frequency of consumption, symptoms of dependence, and consequences of consumption), it can be concluded that the experimental group showed better results in the second assessment (after the BIs), reducing the quantity and frequency of alcohol consumption.

In relation to the consequences of consumption, the experimental group showed better results, with a decrease in the frequency of feelings of guilt or remorse for having drunk and the expression of alcohol consumption-related concerns by a family member, friend, physician or healthcare professional. Before the BIs, 29 individuals in the experimental group were in Zone I, therefore in a low-risk zone. After the development of these interventions, all participants in the experimental group remained in this Zone. Initially, two individuals were in Zone II. After the BIs, these individuals reduced their risk level, and moved to the low-risk zone, Zone I. No individuals in the experimental group were in Zone III, the harmful consumption zone. In the control group, although one individual had reduced the risk level, moving from Zone II to Zone I, the remaining individuals in Zone II (two individuals) and Zone III (one individual) maintained their risk level between the two assessments. The remaining 24 participants were in Zone I.

Taking into account the risk zone of participants in the experimental group, 29 educational interventions, following a previously defined protocol (Zone I), and two simple advice interventions (Zone II) were implemented.

With regard to alcohol consumption in this sample, we did not observe a high consumption, since most individuals, both in the experimental and in the control group, were already in Zone I in their first assessment (low-risk level, with a consumption of $0-40 \mathrm{~g}$ alcohol/day). This result is not in line with the results of other studies (Silva \& Quintas, 2010; Szabo \& Zakhari, 2011) which suggest that alcohol consumption among individuals with HIV is often twice as higher than the consumption among the general population. This fact can be explained by the high level of therapeutic adherence, which translated into an undetectable or $<50$ copies/ml viral load in both groups and in more than half of the individuals. It should be noted that these individuals are aware of their diagnosis for approximately 10 years, and are also being followed-up in consultation for almost that long by the same nurses who have been providing care since the Day Hospital of Infectious Diseases of the General Hospital (now closed) started operating. WHO (2003) argues that the relationship between healthcare professionals and patients is a determining factor for therapeutic adherence. Patients should be able to identify skills, qualities, clear communication and compassion, whereas professionals should be able to encourage patients to have an active role in their treatment and decision-making process, as well as in the compliance with the therapeutic regimen. Although the usual teaching seems to have positive effects in individuals with HIV followed-up in the 
Day Hospital for Infectious Diseases of the General Hospital, we concluded that BIs are more effective in reducing the risk of alcohol consumption. Several studies have underlined that questioning about alcohol consumption and providing feedback on the risk level can contribute to positive changes in consumption (McCambridge \& Kypri, 2011). However, the brief intervention systematically developed by the psychiatric and mental health nurse proved to be more effective. Although we found no studies on the effect of BIs among this specific population, evaluation studies on the effect of BIs both in primary health care and in other specific settings have confirmed their effectiveness (Barroso et al., 2010; Kaner et al., 2007; McCambridge \& Kypri, 2011; Rosa et al., 2015).

The studies of Strauss, Munoz-Plaza, Tiburcio, and Gwadz, (2012) on the implementation of early detection and BIs among healthcare professionals caring for individuals with HIV identified the following major barriers: lack of time for screening; the professionals' perception that their patients' level of alcohol consumption is not worrying; and the lack of information about the patients' level of alcohol consumption. They also identified the following facilitators: adequate time for screening and intervention; availability of information, instruments and materials; and guidelines for the development of interventions, namely on the use of a brief intervention tool.

The integration of the detection of hazardous and/or harmful consumption levels and the implementation of brief nursing care interventions to individuals with HIV require previous awareness raising and training processes on this issue.

\section{Conclusion}

We emphasize the positive effect of BIs in reducing the risk of alcohol consumption among individuals with HIV being followed-up in a specialized consultation, although this lies on the threshold of significance. We observed a positive evolution towards a lower risk of consumption in the experimental group when compared with the control group, so the initial research hypothesis was confirmed.

The effect of BIs which were systematically implemented by the psychiatric and mental health nurse was analyzed by comparing these interventions with the usual teaching provided unsystematically by the generalist nurse, so the control group was also expected to show some effects.

We suggest that further studies should be developed in order to characterize alcohol consumption among individuals with HIV, since the results found in our study are not in line with those found in international studies. This would be important to understand if this is a characteristic of this particular sample or of this population in Portugal.

We believe that it would be appropriate, for example, to apply the AUDIT questionnaire and the BIs in nursing consultations in other day hospitals of infectious diseases, as we have done in this study.

The next step seems to be the training of healthcare professionals, namely those nurses, who, due to their specific skills, are in the best position to develop this type of interventions. In the near future, we expect these interventions to be disseminated throughout the country in a variety of settings, since alcohol consumption is a current health issue in Portugal since very young ages.

\section{References}

Babor, T. F., Higgins-Biddle, J. C., Saunders, J. B., \& Monteiro, M. G. (2001). The alcohol use disorders identification test: Guidelines for use in primary care $\left(2^{\text {nd }}\right.$ ed.). Geneva, Switzerland: World Health Organization, Department of Mental Health and Substance Dependence.

Balsa, C., Vital, C., \& Urbano, C. (2013). III inquérito nacional ao consumo de substâncias psicoactivas na população portuguesa. Lisboa, Portugal: Universidade Nova de Lisboa, Centro de Estudos de Sociologia.

Barroso, T., Castanhola, R., Marta, M., \& Claro, M. (2010). Effectiveness of brief interventions by clinical nurse specialists (CNS) in primary settings. Alcoholism Clinical and Experimental Research, 34(8), 128A

Bonolo, P. D., Gomes, R., \& Guimarães, M. (2007). Adesão à terapia anti-retroviral (HIV/aids): Fatores associados e medidas da adesão. Epidemiologia e Serviços de Saúde, 16(4), 261-278. doi: 10.5123/S1679-49742007000400005.

Bryant, K. J., Nelson, S., Braithwaite, S., \& Roach, D. (2010). Integrating HIV/AIDS and alcohol research. Aging, 33(3), 167178. Retrieved from http://pubs.niaaa.nih.gov/publications/ arh333/167-178.pdf

Chander, J., Lau, B., \& Moore, R. (2006). Hazardous alcohol use: A risk factor for non-adherence and lack of suppression in HIV infection. Journal of Acquired Immune Deficiency Syndromes, 43(4), 411-417. doi: 10.1097/01. qai.0000243121.44659.a4 
Instituto Nacional de Saúde Dr. Ricardo Jorge. (2015). Infeção VIH/SIDA: A situação em Portugal a 31 de dezembro de 2014. Lisboa, Portugal: Autor.

Joint United Nations Programme on HIV/AIDS. (2016). Global aids update. Geneva, Switzerland: Author.

Kaner, E. F., Dickinson, H. O., Beyer, F. R., Campbell, F., Schlesinger, C., Heather, N., . . . Pienaar, E. D. (2007). Effectiveness of brief alcohol interventions for primary care populations. Cochrane Database of Systematic Review, 2(CD004148). doi: 10.1002/14651858.CD004148.pub3

Lingford-Hughes, A., Potokar,J., \& Nutt, D. (2002). Treating anxiety complicated by substance misuse. Advances in Psychiatric Treatment, 8(2), 107-116. doi: 10.1192/apt.8.2.107

Machtinger, E. L., \& Bangsberg, D. R. (2006). Adherence to HIV antiretroviral therapy. Retrieved from http://hivinsite.ucsf. edu/InSite?page $=$ kb-00\&doc $=$ kb-03-02-09

McCambridge, J., \& Kypri, K. (2011). Can simply answering research questions change behaviour?: Systematic review and meta analyses of brief alcohol intervention trials. PloS One, 6(10), e23748. doi: 10.1371/journal.pone.0023748

Rosa, N. R., Abreu, Â. M., \& Barroso, T. M. (2015). Efeito das intervenções breves na redução do consumo de risco nos utentes em tratamento com metadona. Revista de Enfermagem Referência, 4(6), 27-34. doi: 10.12707/ RIV14082
Silva, T., \& Quintas, J. (2010). Consumo de álcool em toxicodependentes em tratamento. Toxicodependências, 16(3), 44-58. Retrieved from http://www.scielo.mec.pt/pdf/ tox/v16n3/v16n3a05.pdf

Strauss, S., Munoz-Plaza, C., Tiburcio, N. J., \& Gwadz, M. (2012). Barriers and facilitators in Implementing "Prevention for Positives" alcohol reduction support: The perspectives of directors and providers in hospital-based HIV care centers. Journal of Association of Nurses in AIDS Care, 23(1), 30-40. doi: 10.1016/j.jana.2011.03.001

Szabo, G., \& Zakhari, S. (2011). Mechanisms of alcohol-mediated hepatotoxicity in human-immunodeficiency-virus-infected patients. World Journal of Gastroenterology, 17(20), 25002506. doi: 10.3748/wjg.v17.i20.2500

Tran, B. X., Nguyen, L. T., Do, C. D., Nguyen, Q. L., \& Maher, R. M. (2014). Associations between alcohol use disorders and adherence to antiretroviral treatment and quality of life amongst people living with HIV/AIDS. BMC Public Health, 14(27), 2-7. doi: 10.1186/1471-2458-14-27

World Health Organization. (2003). Adherence to long-term therapies: Evidence for action. Geneva, Switzerland: Author.

World Health Organization. (2010). Global strategy to reduce the barmful use of alcohol. Geneva, Switzerland: Author.

World Health Organization. (2014). Global status report on alcobol and health: 2014. Geneva, Switzerland: Author. 
